\title{
Regarding Two Abstract Principles of Distributive Justice. A Problem Dealing with Socialist Transformation
}

\author{
Wei Xiaoping \\ Chinese Academy of Social Sciences, CN
}

XIAOPING, W.: Regarding Two Abstract Principles of Distributive
Justice. A Problem Dealing with Socialist Transformation.
Philosophica Critica, vol. 3, 2017, no. 2, ISSN 1339-8970, pp. 3-14.

Distributive justice includes two different principles: justice of remuneration and justice of equality. Justice of remuneration is based on the link between individual contributions and rewards, while justice of equality is based on satisfying the basic needs of individuals regardless of their contribution, which, if understood from the perspective of justice of remuneration, means justice beyond remuneration or adjusted justice. In light of the former, Marx's criticism of young Hegelians' radically critical theories and his criticism of national economics were not targeted at abstract principles but at demonstrating that in real capitalist economic relations, abstract principles move toward their opposites. In light of the latter, Marx in his late years discussed theoretically the transition from the first principle to the second one with changes in production relations and the development of productivity. However, the actual situation is more complicated. China's socialism and its reform practices create many theoretically difficult issues at the level of reality. Paper attempts to discuss different issues revealed by these two principles in different economic relations from the two aspects of abstract principles and actual practice, and demonstrate the modern value of Marxist politico-philosophical thought.

Key words: Distributive justice - Justice of remuneration - Justice of equality

Just as its name implies, justice of remuneration is justice of reward. It is the judgment of positive correlation between labor subjects in objective activities and results of their activities. "Giving more pay for more work, less pay for less work and no pay for those doing nothing" is a popular understanding of this principle. Justice of equality is understood by people from different aspects such as points of departure, procedures and results. Justice of equality as understood from the 
aspects of points of departure and procedures and justice of remuneration complement each other, while justice of equality as understood from the aspect of results is a kind of correction of the results of justice of remuneration. The divergence between Marxism and liberalism results from the existence of justice of remuneration in the form of a paradox in certain relations instead of the principle of justice of remuneration. Justice of remuneration is the basis of argumentation of liberal theories, but through analysis of capitalist relations of production, Marx demonstrated that their economic model subverts the basis of their argumenttation. Consistent with this critical approach, Marx expected that change in capitalist relations of production could be a path of solution, and he further discussed the issue of the relationship between justice of remuneration and justice of equality within the framework of changed relations of production in his late years. The idea of justice of equality strikes a responsive chord with modern foreign Marxist scholars and other left-wing scholars and left-wing liberals, who have two different tendencies. First, different from Marx, the approach of some of today's foreign left-wing scholars is again to focus on moral critique with the language of politico-philosophy. Second is to neglect or fail to pay enough theoretical attention to socialism's extensive setbacks at the end of last century and new changes in modern capitalism's development, which leaves much room for thinking and development of modern research on Marx's philosophical thoughts.

\section{Positive Correlation between Justice of Remuneration and Mechanisms Driving Social Development}

Individually-based justice of remuneration is the accepted basis of liberal theories and the dynamic mechanism in capitalist relations of production. No matter if new or old liberalists, no matter if they are left-wing or right-wing, they do not disagree on this basis. This basis drove people's production and business activeties during simple commodity exchange. In the course of further development of the commodity economy, when the labor force became a commodity and capital was formed, it still drove people's production and business activities, but at that time, the content of remunerating justice changed silently when workers sold their labor force to capitalists. The division of rich and poor became the new norm for the system of capital operations in legal process instead of relying on factors such as natural differences, individual efforts, violence or accidental events.

In Marx's times, some critical theorists were confused by principles and the phenomenon of the paradox of these principles and looked for some way of solving these issues. For example, Proudhon attempted to achieve distributive justice through an appeal for a so-called fairness wage (Marx 1992, Marx 2007). This 
view understands the exploitative relationship as an imbalance between laborer and capitalists in the game for barging interests and holds that exploitation does not exist if wages are rational. Even today, we often hear similar views.

This approach does not theoretically recognize that the principle of justice of remuneration already exists in this economic relations in paradox, but it still plays the role of a driving mechanism in economic operations as the principle of an objective relationship between subjects and objects and in the form of an illusion, and still exerts an influence as an ideology in false manifestations of subverted content. Marx's theory of labor value is the only theory that attempts to demonstrate from the mode of production the process of capital's possession of workers' surplus labor value through profit and continuous accumulation and selfaccumulation. The end of profit also means the end of capital.

The dispute over the paradox of "justice and equality" between modern foreign Marxist scholars and liberal scholars seems tangled up with the two different connotations of "justice of remuneration" and "justice of equality". The actual issue is still how to comprehend and understand the real paradox of "justice of remuneration" in capitalist economic relations.

While criticizing Proudhon and Stirner, instead of directly criticizing the accepted basis, Marx revealed how this basis went to its opposite in actual economic relations. In Marx's early years, he uses alienation theory to reveal that workers' labor fruits were appropriated by capitalists, what resulted in strengthening of the forces of capitalists who could further oppose laborers; Marx criticizes this phenomenon of social alienation. After he turned on to political-economic critical research, he uses surplus value to demonstrate the alienated labor. Consistent with this critical approach, Marx does not treat distribution from distribution as other critics, he explored the occurrence of, and solution to this issue by tracking the relations of production, in the hope of achieving remunerative justice, i.e. distribution according to contribution, through changes in relations of production.

However, even if relations of production change, public ownership of means of production replaces private ownership, and justice of remuneration is thus achieved by relying on the principle of distribution according to contribution under the condition of abolishing private capital's control of and its right to use surplus value, it does not mean the idea of justice of equality would be achieved. In Critique of the Gotha Program, Marx criticized the basic view of the German Workers Party's program, which stated that where private possession of means of production is abolished, wealth from social labor belongs entirely and equally to all members of society.

In light of this, Marx analyzed the fact that distribution according to contribution was still, in principle, differential distribution under the changed relations of production because of the existence of various subjective and objective circumstances, such as individual ability and family size. Socialist practices of the $20^{\text {th }}$ 
century show that, even if such differential distribution exists, its quantitative difference is still limited because accumulated differences can transform into means of production through accumulated labor under certain conditions. At the time, Marx's critical approach did not touch on the possibility of recapitalization of such accumulation. This is because, on the one hand, private ownership of means of production was prohibited and, on the other hand, a commodity economy in the strict sense did not exist, so the term of "contribution" in the principle of distribution according to contribution actually could not be quantified in overall economic relations. As such, socialist practices to some extent followed a relatively egalitarian distribution principle, i.e. neglecting the relevance between individuals' contribution and reward in strict sense, especially restricting development of such relevance towards interpersonal relations (that is transformation of objectivized fruits of labor into objectivized means of labor). However, while preventing transformation, they also made it hard for justice of remuneration to play its role, in deep sense, driving economic development.

Therefore, under changed relations of production, justice of remuneration as a positive driving mechanism of productive and economic activities - even under the condition that abolished private ownership of means of production by which it brings about a paradox - can hardly show its power, so social and economic development still lacks vitality.

The issue of distributive justice is closely related to the dynamic mechanisms of economic development. The reform and opening policy basically aimed at strengthening the principle of justice of remuneration, unleashing economic vitality (in the early period of reform and opening up, such as land contracting, bonuses and incentives, and incentive mechanisms as substituting tax hand in for profits hand in) from the overall perspective of individuals and different levels of unit, and expanding a series of reform measures from countryside to cities. However, as a result of the natural attributes of justice of remuneration, differences accumulated under certain conditions transform into objective existence (capital) through accumulated labor and give rise to the issue of its own paradox again, and make justice of remuneration an illusory form in reality under certain conditions. Here we temporarily put aside other paths of privatization of means of production, such as the introduction of foreign capital, privatization of state-owned assets and establishment of a shareholding system.

Liberal scholar Robert Nozick's demonstration of the principle of self-ownership and its chain of justice is based on justice of remuneration, so he opposes egalitarianism, closely combines justice of remuneration and liberty, making it a factor opposite to equality (Nozick 2001) - here equality refers to results instead of opportunities - and completely ignores the reality that justice of remuneration has gone to its opposite in capitalist economic relations. Left-wing scholar G. A. Cohen (one of the founders of Analytical Marxism), who turned to the field of 
politic-philosophical criticism, thoroughly criticized Nozick's chain of justice using the concept of naturally equal right to natural resources, by demonstrating its inevitable contradiction with liberty and rights, i.e. unequal private property rights inevitably harm naturally equal rights between man and natural resources.

Unlike foreign academic circles where related disputes mainly unfolded around the concepts of liberty and equality, disputes within China academic circles in the early period of reform and opening up mainly focused on the concepts of efficiency and fairness. Unlike traditional systems in which the idea of egalitarianism occupies a dominant position, reform and opening up emphasizes giving priority to efficiency with due consideration to fairness. Giving priority to efficiency means stimulating subjects' economic motivation by emphasizing the principle of justice of remuneration.

In the early period of reform and opening up, this was realized through the land contracting system, the obvious effect and quick reaction have been proved by the results of reform. The theoretical principle contained in land contracting is unleashing the initiative of labor subject through certain changes in economic relations, letting them pursue the positive correlative effect of the objective relationship between subjects and objects in the course of labor under certain conditions, objectively promoting economic development, and showing a positive correlation between enhancement of the principle of justice of remuneration and dynamic mechanisms for social development.

\section{Positive Correlation between Justice of Equality and Mechanisms of Social Progress}

Justice of remuneration reflects the positive correlative effect of the mechanism of association between subjects and objects. Marx never directly criticizes on this principle itself. In his early years, he deciphered the opportunity for the occurrence of the paradox of justice of remuneration in the historical course of changes in the relations of production. This opportunity has two preconditions: the first is private ownership of means of production, and the second is the formation of capital relations characterized by commercialization of labor force. Accordingly, Marx's countermeasure is the possession of means of production by society and a planned economy. He demonstrated the preconditions of such a change in relations of production within the course of historical development, i.e. public ownership of means of production compatible for large-scale socialized production and a planned economy coordinating with it.

Under this situation, the idea of equality seems to be guaranteed by the socialist economic system. However, realization of justice of remuneration from the indivi- 
dual and local perspective is obviously a problem. This is not only because a strict economic accounting system can hardly function if the boundaries of ownership of means of production are unclear, but also because justice of remuneration means differential distribution and its natural tendency of free development will ultimately threaten the idea of equality. As such, there is still a tense relationship between justice of remuneration and justice of equality. In reality, all traditional socialist countries implementing the principle of distribution according to contribution strictly limit the scale of the private economy, the difference in individual rewards, and cut the tail of capitalism. Unlike the Soviet Union, some traditional socialist countries in Eastern Europe (Central Europe: geographical definition) had more experience of capitalist enlightenment before World War II. Their attempts to let justice of remuneration develop freely and to open a gap for the market economy in the 1950s and 1960s was deemed by the Soviet Union as rebellion against orthodoxy. The socialist idea of equality was replaced by actual egalitarianism in practice.

Marx also realized the existence of this issue and discussed it in Critique of the Gotha Program by analyzing and criticizing Lassalle's view that equal distribution is income from labor without any discount. He put forward the view that distribution according to contribution can only be one kind of differential distribution in reality and so is still a civil right, otherwise translated as bourgeois legal right (Marx - Engels 1985, 14), and proposed the idea that distribution according to need will replace distribution according to contribution under certain developed productive conditions. This is not only another countermeasure of Marx, but it also can be regarded as the manifestation of Marx's early humanist ideas.

Theoretically speaking, the principle of distribution according to need, based on individuals' need for living materials, ignores the link between his/her contributions and rewards, not only freeing the society from capitalist economic relations which is full of antagonistic contradictions, but also emancipating individuals from the economic pressure of earning a living, thus making their activities no longer subject to individual material pressure. So it has become a path of selfimprovement in objective activities and realizing a model of human being development truly different from the law of jungle under capitalism. This is the Marxian humanitarian appeal pursued by Marx, which differs from the connotations of justice of remuneration and contains the idea of justice of equality. As a result of this, justice of remuneration has become redundant, and from the perspective of theoretical assumptions, the antagonistic contradictions contained in justice of remuneration no longer exist. It was in this sense that Marx deemed such a society the beginning of real human society (Marx - Engels 1980, 101; Marx - Engels 1998, 413). In comparison, previous societies are all prehistoric ones.

The idea of equality as an appeal of left-wing in capitalism dealing with the division between rich and poor has different meanings because of different beliefs 
and knowledge. The idea of the justice of equality of the left-wing within liberal scholars is compared with its right-wing's libertarian view. For example, the views of Rawls and Nozick represent typical differences among liberals. Nozick pushed the principle of justice of remuneration to the extreme perspective of individual liberty and demonstrated capital accumulation with the so-called chain of justice. He never realized that justice of remuneration moved to its opposite in capitalist economic relations and, in defense of individual liberty, he opposed relying on compulsory taxation to adjust the gap between rich and poor to realize a kind of equality, thus setting justice of remuneration and justice of equality into opposition.

Rawls also followed liberal ideas but formed different theories. He conceived an ideal society from the perspective of free choice, and presumed two principles for this society, namely, the liberty principle and difference principle. The former contains justice of remuneration, while the latter contains justice of equality based on efficiency brought about by the former. In his opinion, in terms of overall results, wealth generated by an efficient society is beneficial to disadvantaged groups. From the point of results, Rawls thought that as long as differential distribution is conducive to improvement of the situation of disadvantaged groups, it is just. He defended capitalist economic relations in the sense of economic efficiency, and at the same time made certain re-adjustment corrections to social divisions inevitably brought about by capitalist economic relations in the sense of social justice and equality.

Compared with Nozick's libertarian theory, Rawls' theory better reflects the idea of social progress. The former is suspected of following the law of the jungle, while the latter contains human self-adjustments on the basis of reflection, i.e. intervention in natural processes. However, as a liberal left-wing scholar knowing a little about Marx's critical approach and influenced by Marx's thought to some extent, Rawls did not directly question that the justice of remuneration in the form of paradox in capitalist mode has brought about the phenomenon of alienation, but accept this mode from the perspective of economic efficiency. That is to say he did not directly challenge the law of the jungle but, under the precondition of acquiescing to its rules, proposed adjusted measures from the standpoint of justice of equality for the inevitable trend of division between rich and poor. Rawls' idea of justice as fairness contains two principles of justice. Justice of remuneration is the precondition coordinated with his idea of liberty, while justice of equality is the remedy for correction of social disruptions formed in relations of production under certain historical conditions.

Cohen, one of the founders of Analytical Marxism, criticized both left-wing and right-wing liberals from the perspective of justice of equality. His criticism of Nozick's liberal idea centered on the principle of self-ownership does not directly 
use Marx's surplus value theory but relies on the idea of the right of resource equality. His criticism of Rawls' idea of justice as fairness is not focused on the liberty principle or difference principle but the precondition of following these principles - the capitalist social structure, arguing that the so-called disadvantaged group is the product of this structure rather than being born that way. Cohen, from the overall perspective of the group rather than the perspective of the individual, criticized capitalist society's class structure for giving rise to a disadvantaged group. In his opinion, the direction of real social progress is not capitalist society providing assistance to the disadvantaged group through corrections but the establishment of a socialist system capable of fundamentally changing this paradox. In the book Why Not Socialism? (Cohen 2019), he expressed this thought. In an actual sense, he accepted capitalist justice of remuneration and adjusted justice existing in accompaniment with its paradox as next-best principles.

Unlike Rawls' pursuit of the idea of justice of equality within the framework of capitalist economic relations in the sense of adjustment through redistribution, Dworkin, on the basis of adhering to the concept of liberalism, included individual responsibility into the institutional framework of justice of equality through a combination of the design of insurance system and people's choices, rather than a compulsory social insurance system. Unlike Rawls' method of pursing a degree of justice of equality by adjusting distribution, Dworkin's concept combines the social insurance system and choices of individuals so as to strengthen individuals' responsibility for their situations, but both he and Rawls avoided the issue of justice of remuneration already existing as a paradox behind the surface in the capitalist social structure.

This shows that the idea of justice of equality pursued by left-wing liberals differs from the idea of justice of equality pursued by Marx in the following two ways: the former is based on the principle of justice of remuneration in capitalist economic relations and its consequence of social divergence, proposes adjust measures to an extent, prevents individuals from falling into difficulties for various reasons by meeting people's basic needs for subsistence, basic education, medical care, employment and old-age pension, realizing social welfare to some extent with compulsory tax policies and implementing a compulsory or voluntary social insurance system, and thus realizes the idea of social justice to some extent and plays a certain positive role in promoting social progress. However, this adjusted approach has to disregard or ignore the existence of justice of remuneration in the form of a paradox in its reality and the social issues accompanying various phenomena of social alienation. Under certain developed historical conditions, the latter attempts to change the capitalist economic relations that the paradox relies upon. On the basis of establishing socialist economic system sets up the rule of distribution according to contribution and then carries out the transi- 
tion from distribution according to contribution to distribution according to need, and further follows the principle of justice beyond remuneration, therefore sublimeting people's activities to earn a living into free creative activities. However, large-scale traditional socialist practices of the last century still demonstrate the importance of justice of remuneration under changed production relations in the practical situation.

\section{Conflict between Principles and Actual Contexts, Entanglement between Theory and Reality}

As two principles in distributive relationship, justice of remuneration and justice of equality involve different objective relationships. Theoretically, justice of remuneration is based on the objective relationship between subjects and objects, and relatively speaking, its connotations are quite clear: it reflects a positive correlation between subjects and objective labor relations and seeks corresponddence between effective contribution and reward, but in certain economic relations, such a relationship is conditioned by mutual relationships among people (subjects). Here we see unification of norms and history; in comparison, the conotations of justice of equality are not that clear. In different historical stages of development and different social systems, its connotations are quite different.

In the capitalist economic system, as opposed to the feudal system, the idea of equality is first understood in terms of citizens' equality of rights, equality of opportunities, etc., and the concept of equality of rights includes equality of remuneration, i.e. what Marx called bourgeois rights (civil rights). After World War II, influenced by the socialist camp, the Western world gradually developed and improved the capitalist welfare system based on adjusted redistribution of the results of distribution according to formal justice of remuneration, and focusing on appeal for the right of survival (the principle of justice beyond remuneration) instead of appeal for civil rights (justice of remuneration), i.e. whether a person can contribute or has contributed effectively to the society or not, he has the basic right to get a minimum surviving substances.

Moreover, the connotations of justice of equality have also changed to some extent. The previous appeal for equality was a demand for equality of rights and opportunities from the feudal system, while the later appeal for equality was the adjustment or modification of the results of legal process. Because the legal process of private property rights and the market economy constantly cause division between rich and poor in society and the division of society, a degree of social adjustment is unavoidable, but such an adjustment does not question the paradoxical state of the justice of remuneration in capitalism. Rawls called it Justice as 
Fairness (Rawls 1971, 251). He added a qualifier to justice, and modified or corrected it fairly.

This view, which is a consensus among left-wing scholars in the Western developed capitalist camp, does not seem to have changed much. The author of Capital in the Twenty-First Century, Thomas Piketty, relying on big data obtained with modern information technology, rather than appealing to Marx's labor value theory, demonstrates that the law of the growing rate of capital is greater than that of national income $(\mathrm{r}>\mathrm{g})$. While belief in liberal values and ideas gradually expands together with the globalization of capital, by demonstrating this law, Piketty points out that the value and ideas enrichment through work, the belief of modern society, are subverted by returning to "hereditary capitalism" (Piketty 2014, 437).

Piketty thus attempts to show that the liberty and market based on enhancing the principle of justice of remuneration actually resulted in the opposite of their original purpose and promoted a change in wealth distribution from reliance on individual contribution to reliance on inheritance. This is the difference between him and Rawls. Piketty's demonstration is more critical of capitalist economic relations, while he does not thoroughly investigate the social mechanisms which subverts this principle like Marx did but puts forward a remedial measure like Rawls did, namely, imposing a progressive tax on capital and promoting this measure around the world so as to put an end to capital flows around the world for the purpose of tax evasion.

The reality of justice of remuneration as an abstract principle is not only restricted by historical context, similarly, whether under the capitalist market economy or under the traditional socialist planned economy, this abstract principle is also conditioned by actual context in different senses: the former is manifested in its functioning in a paradox which causes continuous expansion of the division between rich and poor in society and its overproduction, while the manifestation of the latter is its limitation in actual operations, resulting in a lack of incentive mechanisms for economic and social development and its underproduction.

The capitalist market economy relies on the idea of justice of equality to inhibit and adjust its shortcomings to some extent via adjusted justice. For Western developed capitalist countries, this is manifested in social welfare systems for things like cost-of-living support, basic education, medical care, unemployment and an old-age pension, which rely on taxation and social security system. In terms of satisfying and guaranteeing people's basic needs, this factor under the capitalist system is sometimes understood by people as a "socialist" factor. Due to the fact that advanced capitalist societies have accumulated their economic foundation over hundreds of years, their ability to satisfy and guarantee people's basic needs is higher than that of traditional socialist countries, which are encumbered by slow economic development. Therefore, some people think these developed 
capitalist countries are more "socialist". In fact, these are two different concepts involving different dual objective relationships. The dramatic collapse of the USSR and changes in Eastern European countries at the end of last century, which changed the strength of peripheral political checks and balances, and the financial crisis at the beginning of this century, which changed internal economic factors, have both greatly reduced the level of social security and welfare in developed capitalist countries and even Northern European countries to varying degrees.

The practice of China's socialist economic reform on the purpose of overcoming the shortcomings of (absolute) egalitarianism by strengthening justice of remuneration has unleashed great initiative and objectively has promoted productivity. However, in the course of reform, amid the coexistence of the market economy and different economic sectors, apart from the path of corruption, divisions between rich and poor have increased constantly in legal process. Correspondingly, unlike the traditional socialist institutional security system, after economic reform, under the condition of socialist market economy, social security system was established on the basis of taxation to satisfy people's basic needs: including cost-of-living support, medical care, unemployment and old-age pension, to some extent, through the channel of redistribution.

Theoretically speaking, satisfying the basic needs of members of society does not directly imply narrowing the gap between the rich and poor. In developed capitalist countries, there is the Northern European model and the American model for satisfying basic needs. Under the more democratic Northern European model, the gap between rich and poor is narrower and the level of social welfare is higher, and under the American model, the gap between the rich and poor is wider and the level of social welfare is lower. However, these two models are both characterized by increasing division between rich and poor in society and only differ in extent.

\section{Conclusions}

Different from Marx's time, today, in addition to traditional industrial capital still performing its basic functions, financial capital and its abstract derivative products are redistributing and re-concentrating social wealth at a speed and on a scale unimaginable compared with traditional industrial capital. Meanwhile, the development of capitalist globalization and the application of modern IT mean that spontaneous capital logic has recurred around the world. A political system for worldwide macro-control obviously does not exist, which is why the issue of global fairness and justice has recently become a popular and thorny issue. 


\section{References}

COHEN, G. A. (2009): Why Not Socialism? Beijing: People's Publishing House. MARX, K. (2007): Economic and Philosophic Manuscripts of 1844. Dover Books on Western Philosophy.

MARX, K. (1992): The Poverty of Philosophy. New York: International Publishers Co.

Marx-Engels-Gesamtausgabe, I/25 (1985). Berlin: Dietz Verlag. Marx-Engels-Gesamtausgabe, II/2 (1980). Berlin: Dietz Verlag. NOZICK, R. (2001): Anarchy, State, and Utopia. Hoboken: Wiley-Blackwell. PIKETTY, Th. (2014): Capital in the Twenty-First Century. Beijing: China CITIC Press.

RAWLS, J. (1971): A Theory of Justice. Cambridge: Belknap Press of Harvard University Press.

The Complete Works of Marx and Engels, Vol. 31 (1998). Beijing: People's Publishing House.

\section{prof. Wei Xiaoping}

Philosophy Institute

Chinese Academy of Social Sciences

Jianguomen Neidajie No. 5

100732 Beijing

China

weixiaoping@hotmail.com 